certain that they grow at an optimum rate. Sherman (1947) has recently pointed out that animals may live through their whole lives, and never have optimum concentrations of calcium in their bones or tissues. The same must be true of man, and those who have had opportunities of studying calorie deficiencies will see the obvious parallel. Given a somewhat insufficient number of calories, children do not fail altogether to grow, but they grow more slowly than they should. Walker and his associates do not seem to have given due consideration to the whole body of evidence which has been produced in England and Denmark. They have concentrated rather on specific parts of it, and until they have produced evidence that the growth of children cannot be improved by the addition of calcium to diets low in calcium and high in phytic acid it would seem wiser to act upon the recommendations of the Danish and British investigators. Anyone who considers that milk is a valuable food for growing children must hesitate before accepting such conclusions as those of Nicholls \& Nimalasuriya or of the South African workers.

\title{
REFERENCES
}

Bruce, H. M. \& Callow, R. K. (1934). Biochem. F. 28, 517.

Cruickshank, E. W. H., Duckworth, J., Kosterlitz, H. W. \& Warnock, G. M. (1945). F. Physiol. 104, 4 I. Harrison, D. C. \& Mellanby, E. (1939). Biochem. F. 33, 1660.

Hoff-Jørgensen, E. (1946). Biochem. F. 40, 189.

Hoff-Jørgensen, E., Andersen, O., Begtrup, H. \& Nielsen, G. (1946). Biochem. F. 40, 453.

Hoff-Jargensen, E., Andersen, O. \& Nielsen, G. (1946). Biochem. F. 40, 555.

Krebs, H. A. \& Mellanby, K. (1943). Biochem. F. 37, 466.

McCance, R. A. \& Walsham, C. M. (1948-9). Brit. $\mathcal{~ Y . ~ N u t r i t . ~ 2 , ~} 26$.

McCance, R. A. \& Widdowson, E. M. (1942a). F. Physiol. rox, 44.

McCance, R. A. \& Widdowson, E. M. (1942b). F. Physiol. Ior, 304.

McCance, R. A. \& Widdowson, E. M. (1943). F. Physiol. 102, 42.

McCance, R. A. \& Widdowson, E. M. (1944). Nature, Lond., 153, 650.

Medical Research Council (1947). Rep. med. Res. Coun., Lond., I939-45. [Cmd. 7335.]

Mellanby, E. (1921). Spec. Rep. Ser. med. Res. Coun., Lond., no. 61 .

Mellanby, E. (1925). Spec. Rep. Ser. med. Res. Coun., Lond., no. 93.

Mellgaard, H. (1946). Biochem. F. 40, 589.

Nicholls, L. \& Nimalasuriya, A. (1939). F. Nutrit. 18, 563.

Pringle, H., Reynolds, K. A. \& Jessop, W. J. E. (1943). F. med. Ass. Eire, p. 67.

Sherman, H. C. (1947). Calcium and Phosphorus. New York: Columbia University Press.

Walker, A. R. P., Fox, F. W. \& Irving, J. T. (1948). Biochem. F. 42, 452.

Widdowson, E. M. (1947). Spec. Rep. Ser. med. Res. Coun., Lond., no. 257.

\section{The Rachitogenic Effect of Yeast}

\author{
By R. Braude and S. K. Kon \\ National Institute for Research in Dairying, University of Reading
}

Our observations are concerned with a deficiency disease in pigs apparently caused by a foodstuff included in a practical ration, but we are uncertain whether the disease was due to an antivitamin in the strict sense of the word, or whether some other explanation may ultimately prove correct.

Dried yeast is a concentrated source of protein and for this reason, quite apart from its content of vitamins of the B complex, it is now generally recognized as a valuable feeding-stuff for animals. In this country the interest in the product was increased by 
wartime shortages of other concentrated foods, and during the last war the use of yeast in the feeding of livestock was studied at Shinfield. Work with dairy cattle and pigs confirmed the high nutritive value of the product, though with pigs some unexpected difficulties were encountered.

In an initial experiment (Braude, Kon \& White, 1943), in which three varieties of yeast were used as a protein supplement in a fattening diet instead of the more usual meat meal or fish meal, the pigs grew well at first but later a few lost their appetite, ceased to grow and became lame.

In planning the diet, allowance was made for the very high phosphorus content of yeast, and subsequent analysis showed that the calcium :phosphorus ratio of the diet was well within the conventional limits.

Poisoning was at first suspected, but analysis of the diet for heavy metals and fluorine gave negative results.

The adequate carotene content of the diet made it most improbable that the lameness was due to lack of vitamin A. It was, however, thought possible that a deficiency of manganese might have been the cause, especially as it was known that this metal is connected with the occurrence of perosis in the fowl and with the metabolism of bone in other species also (Barnes, Sperling \& Maynard, r94I; Miller, Keith, McCarty \& Thorp, 1940). Moreover, Perla (1939) had shown that in rats the requirement for manganese was increased in the presence of large quantities of vitamin $B_{1}$. Nevertheless, treatment with manganese proved entirely unsuccessful.

At this stage we were joined in our work by $\operatorname{Dr}$ E. G. White, then of the Royal Veterinary College, and the possibility that the pigs were suffering from an infective arthritis was next considered. The affected pigs were slaughtered for bacteriological and histological examination. No evidence of infection was found, but the histological picture showed lesions typical of rickets in the pig as described by many authors, notably Marek \& Wellmann (1931).

In further experiments (Braude et al. 1943) the percentage of yeast in the diet was increased from 8 to 20 , and the symptoms, which under these conditions appeared earlier and with greater severity, were identified as rickets by histological and X-ray examination of the bones and by determination of the calcium level in the blood. Pigs, which received vitamin $\mathrm{D}$ added to the $20 \%$ yeast diet, remained entirely free from symptoms, and it is interesting in this connexion that a dose of $2 \mathrm{~g}$. of irradiated yeast daily was fully protective. By these observations the practical problem of the use of yeast in pigs' diets was solved, as it could safely and with benefit be included in diets containing $0.5 \%$ of cod-liver oil.

The explanation of the rachitogenic effect of yeast was by no means so clear and, even now after much further work (Braude et al. 1944; Braude, Henry \& Kon, 1948-9), we are still unable to offer a satisfactory explanation.

We found that the effect of yeast could be partly counteracted by further addition of calcium carbonate to the diet, and that the beneficial effect was due to calcium as such, and not to the alkaline nature of the supplement, since sodium carbonate in equivalent quantities was ineffective.

We satisfied ourselves also that the phosphorus of yeast was, in all probability, not 
directly responsible for the rickets, for we could not produce the condition by giving inorganic phosphorus as sodium acid phosphate in quantities in excess of those supplied by yeast.

The diets used by us contained about $75 \%$ of cereals and were therefore relatively rich in phytic acid. It is known (Pedersen, 1940; Møllgaard, Lorenzen, Hansen \& Christensen, 1946) that phytic acid is normally hydrolysed in the intestine of the pig by the phytase present in the majority of cereals. It seemed possible that yeast might in some way interfere with this hydrolysis and that this would affect the availability of calcium and phosphorus and lead to rickets. The findings of Hoff-Jørgensen (1947) supported this possibility. However, experiments with pigs in which the phytase activity of some of the diets was destroyed by heating gave entirely negative results. Tests in vitro also failed to demonstrate any inhibition of phytase by dried yeast. This observation was confirmed very recently by de Man (1948) and by HoffJørgensen (1948) himself.

Preliminary tests have indicated that live yeast might be less rachitogenic than dried yeast, and further work on this is in progress.

As things stand at present we still do not know why yeast causes rickets in the pig. Under our conditions the sows and their litters receive vitamin D from cod-liver oil during the suckling period, but no further vitamin $\mathrm{D}$ is given during fattening. Probably towards the end of the fattening period the vitamin $\mathrm{D}$ reserves are running low and, in these circumstances, a relatively small change in the vitamin $D$ requirements of the pig, or in the amount present in the diet, or in the calcium and phosphorus metabolism of the pig, may lead to rickets, and yeast may contribute in any of these directions.

It is of interest that pigs receiving yeast had larger livers (Braude, Henry, Kon \& Thompson, 1947), but smaller liver reserves of vitamin A (Braude et al. 1943, 1944, 1947), than pigs similarly treated but not given yeast.

\section{REFERENCES}

Barnes, L. L., Sperling, G. \& Maynard, L. A. (1941). Proc. Soc. exp. Biol., N.Y., 46, 562. Braude, R., Henry, K. M. \& Kon, S. K. (1948-9). Brit. F. Nutrit. 2, 66.

Braude, R., Henry, K. M., Kon, S. K. \& Thompson, S. Y. (1947). Brit. F. Nutrit. 1, vi.

Braude, R., Kon, S. K. \& White, E. G. (1943). F. comp. Path. 53, i6r.

Braude, R., Kon, S. K. \& White, E. G. (1944). F. comp. Path. 54, 88.

Hoff-Jørgensen, E. (1947). Nature, Lond., 159, 99.

Hoff-Jørgensen, E. (1948). Nature, Lond., 162, 575.

Man, T. J. de (1948). Nature, Lond., 162, 574.

Marek, J. \& Wellmann, O. (1931). Die Rhachitis (Pathologischer Teil). Jena: Gustav Fischer.

Miller, R. C., Keith, T. B., McCarty, M. A. \& Thorp, W. T. S. (1940). Proc. Suc. exp. Biol., N. Y., 45, 50.

Møllgaard, H., Lorenzen, K., Hansen, I. G. \& Christensen, P. E. (1946). Biochem. Y. 40, 589.

Pedersen, J. G. A. (1940). Beretn. Forsogslab. Kbh. no. 193.

Perla, D. (1939). Science, 89, 132. 